\title{
STRATEGI KEPALA SEKOLAH DALAM MENINGKATKAN KUALITAS PEMBELAJARAN DAN ETOS KERJA GURU DI SD NEGERI 05 KOTO TANGAH KECAMATAN TANJUNG EMAS KABUPATEN TANAH DATAR
}

\author{
Abu Nawas \\ Pengawas Pendidikan Agama Islam (PAI) Kabupaten Tanah Datar \\ Komplek Penum Talago Ponai Indah, Kec. Rambatan, Tanah Datar
}

$+20$

\begin{abstract}
In this qualitative study, the researcher analyzed the headmaster's strategy on upgrading the quality of instruction and teachers' work ethos in Primary School 05 Koto Tangah, Tanjung Emas, Tanah Datar. The results revealed that the strategies were applied by the headmaster 1) encourage teachers to be creative and innovative; 2) discipline; 3) give an advice on making lesson plan; 4) supervise the class; 5) complete the instructional infrasructure; and 6) upgrade the instructional evaluation. The strategies changed the teachers' work ethos especially on teachers' mindset.
\end{abstract}

Keywords: Headmaster's Strategy, Quality of Instruction, Teachers'Work Ethos, Primary School, Tanah Datar

\section{PENDAHULUAN}

Pendidikan merupakan kebutuhan mendasar bagi kehidupan manusia, sebagai makhluk ciptaan Tuhan yang terbaik dalam mengembangkan potensi yang dimilikinya. Allah berfirman dalam QS. AtTin "sesungguhnya Kami telah menciptakan manusia dalam bentuk yang sebaik-baiknya. Kemudian Kami kembalikan ke tempat yang serendah-rendahnya. Kecuali orang-orang yang beriman dan mengerjakan amal saleh, maka bagi mereka pahala yang tiada putusputusnya" (QS. At-Tin 4-6). Keutamaan manusia dari makhluk lainnya terletak pada kecerdasan akalnya. Untuk meningkatkan kemampuan akal dan kecerdasan manusia itu, Allah Swt menurunkan firmanNya dalam QS. al-Alaq "bacalah dengan (menyebut) nama Tuhanmu yang menciptakan. Dia telah menciptakan manusia dari segumpal darah. Bacalah dan Tuhanmulah yang Paling Pemurah. Yang mengajar (manusia) dengan perantaraan kalam. Dan mengajarkan kepada manusia apa yang tidak diketahuinya" (QS. al-Alaq: 1-5).

Setelah manusia bisa membaca dan menulis, manusia dapat mengetahui sesuatu yang berada di alam semesta dan apa yang berada di balik alam nyata ini. Melalui proses, membaca, menulis dan mengetahui, kemudian beriman, maka manusia mendapat posisi yang tinggi derajatnya sebagaimana firman Allah dalam QS. al- Mujadalah 
"hai orang-orang yang beriman, apabila dikatakan kepadamu berlapanglah dalam majlis maka lapangkanlah, niscaya Allah akan memberi kelapangan untukmu. Dan apabila dikatakan berdirilah kamu, maka berdirilah, niscaya Allah akan meninggikan orang-orang yang beriman di antaramu dan orang-orang yang diberi ilmu pengetahuan beberapa derajat. Dan Allah Maha Mengetahui apa yang kamu kerjakan" (QS. al- Mujadalah: 11). Kemudian Allah berfirman dalam QS. Az-Zumar "katakanlah, adakah sama orangorang yang mengetahui dengan orang-orang yang tidak mengetahui? Sesungguhnya orang yang berakallah yang dapat menerima pelajaran" (QS. Az-Zumar: 9). Selanjutnya Allah berfirman dalam QS. Yunus "Dialah yang menjadikan matahari bersinar dan bulan bercahaya dan ditetapkan-Nya manzilahmanzilah (tempat-tempat) bagi perjalanan bulan itu, supaya kamu mengetahui bilangan tahun dan perhitungan (waktu) Allah tidak menciptakan yang demikian itu melainkan dengan hak. Dia menjelaskan tanda-tanda kebesaran-Nya kepada orang-orang yang mengetahui" (QS. Yunus: 5).

Dari Abu Musa, dari Nabi SAW bersabda "petunjuk dan ilmu dari Allah yang harus aku sampaikan diumpamakan seperti hujan deras yang menimpa tanah, di antara tanah itu ada yang bersih, sehingga dapat menerima air, lalu menumbuhkan rumput-rumputan yang banyak. Ada pula tanah yang gersang, sehingga menahan masuknya air, lalu Allah memberi manfaat tanah itu kepada manusia. Jadi, manusia bisa minum, memberi minum (ternaknya), dan menanam. Air hujan itu menimpa (pula) tanah lainnya, yaitu tanah rata yang tidak dapat menahan air, juga tidak dapat menumbuhkan rumput-rumputan. Itulah perumpamaan orang yang pandai tentang agama Allah dan mendapat manfaat dari yang telah Allah SWT. turunkan kepadaku. Dia mengetahui agama dan mengajarkannya (kepada orang lain) dengan orang yang tidak mengangkat kepala untuk itu dan tidak menerima petunjuk Allah yang di turunkan kepadaku" (Azzabidi, 1996).

Dari firman Allah dan hadis yang dikemukakan di atas dapat diketahui bahwa ilmu dan pengetahuan itu mengantarkan manusia yang selalu berfikir dan menganalisis gejala alam kearah berilmu pengetahuan yang dilandasi dengan zikir dan fikir kepada Allah menghasilkan berbagai jenis perangkat alat-alat teknologi untuk memajukan kesejahteraan hidup di dunia dan kebahagiaannya di akhirat. Dalam perkembangan zaman, ilmu dan teknologi, mengharuskan adanya peningkatan kualitas sumber daya manusia. Salah satu usaha dalam meningkatkan kualitas sumber daya manusia itu adalah melalui proses pembelajaran di sekolah. Proses pembelajaran di sekolah itu ditetapkan berdasarkan jenjang pendidikan yang terdiri dari pendidikan dasar, menengah dan tinggi. Secara keseluruhan, jalur pendidikan di Indonesia mengacu pada tujuan pendidikan nasional yang terdapat dalam pasal 3 Bab II Undang-undang nomor 20 tahun 2003 yang berbunyi "pendidikan 
nasional berfungsi mengembangkan kemampuan dan membentuk watak serta peradaban bangsa yang bermartabat dalam rangka mencerdaskan kehidupan bangsa, bertujuan untuk berkembangnya potensi peserta didik, agar menjadi manusia yang sehat, berilmu, cakap, kreatif, mandiri dan menjadi warga negara yang demokratis serta bertanggung jawab (Departemen Agama RI, 2006).

Tercapai atau tidaknya tujuan Pendidikan Nasional sebagaimana yang terdapat di dalam Undang-Undang di atas, tidak terlepas dari kepemimpinan Kepala Sekolah. Hal ini disebabkan Kepala Sekolah merupakan orang yang menggerakkan dan mempengaruhi seluruh personil yang ada dalam organisasi atau lembaga untuk bekerja sesuai dengan tugas yang telah ditentukan sehingga tercapai tujuan yang telah ditetapkan. Kepala Sekolah harus mempunyai kemampuan dalam meningkatkan kualitas guru, sarana dan prasarana, kualitas proses pembelajaran dan evaluasi.

Kepala Sekolah merupakan pemimpin pendidikan yang menempati posisi terdepan dan strategis dalam mengatur jalannya proses pembelajaran, administrasi dan hubungan antara sumber daya manusia, baik antara sesama guru, staf atau karyawan dan masyarakat lingkungannya serta antara sekolah dan wali murid. Pandangan ini sesuai dengan pendapat yang dikemukakan oleh Amentembun (1982) "Kepala Sekolah menempati posisi terdepan dalam arena belajar mengajar yang dipimpinnya dan secara fungsional ia adalah puncak tanggung jawab atas proses pembelajaran yang berlangsung".

Berdasarkan uraian di atas, dapat dikatakan bahwa Kepala Sekolah berperan sebagai supervisor, administrator, fasilitator dan motivator. Oleh karena itu dia harus menempati posisinya dengan baik dan benar dalam rangka meningkatkan kualitas dan profesi para guru dalam proses pembelajaran. Sebagai seorang pemimpin, tugas dan tanggung jawab yang harus dilaksanakan oleh Kepala Sekolah sangat berat. Oleh karena itu seorang Kepala Sekolah harus punya kemampuan sebagai seorang pendidik. Mulyasa (2012) mengungkapkan bahwa Kepala Sekolah yang efektif terlihat pada 1) mampu memberdayakan pendidik dan tenaga kependidikan serta seluruh warga sekolah lainnya untuk mewujudkan proses pembelajaran yang berkualitas, lancar dan produktif; 2) dapat menyelesaikan tugas dan pekerjaan secara tepat waktu dan tepat sasaran; 3) mampu menjalin hubungan yang harmonis dengan masyarakat sehingga dapat melibatkan mereka secara aktif dalam rangka mewujudkan visi dan misi sekolah serta tujuan pendidikan; 4) mampu menerapkan prinsip kepemimpinan yang sesuai dengan tingkat kedewasaan pendidik dan tenaga kependidikan lain di sekolah; 5) dapat bekerja secara kolaboratif dengan tim manajemen sekolah; 5) dapat mewujudkan tujuan sekolah secara efektif, efisien, produktif dan akuntabel sesuai dengan ketentuan yang telah ditetapkan. 
Dari pendapat yang dikemukan di atas dapat diketahui bahwa Kepala Sekolah dalam melaksanakan tugasnya sebagai pendidik, harus memiliki strategi yang tepat untuk meningkatkan profesionalisme tenaga kependidikan di sekolahnya. Upaya yang dapat dilakukan Kepala Sekolah dalam meningkatkan kinerja sebagai pendidik, khususnya dalam meningkatkan kerja tenaga kependidikan dan prestasi belajar peserta didik dapat digambarkan dengan mengikutsertakan guru-guru dalam penataraan untuk menambah wawasan para guru. Memberikan kesempatan kepada guruguru untuk meningkatkan pengetahuan dan keterampilan dengan belajar ke jenjang pendidikan yang lebih tinggi.

Di samping itu Kepala Sekolah sebagai pemimpin mempunyai tugas tersendiri dalam pembinaan dan pengembangan kurikulum dan semua tugas supervisor harus selalu berlandaskan pada kurikulum sekolah. Untuk melaksanakan kurikulum dengan sebaik-baiknya diperlukan adanya kemauan dan kecakapan guru-guru di bawah bimbingan dan pengawasan Kepala Sekolah.

Dalam masalah pembinaan dan pengembangan kurikulum, Kepala Sekolah semestinya melakukan antara lain 1) membimbing para guru untuk dapat meneliti dan memilih bahan-bahan pelajaran mana yang baik dan sesuai dengan perkembangan anak dan tuntutan kehidupan masyarakat; 2) membimbing dan mengawasi guru-guru agar mereka pandai memilih metode-metode mengajar yang baik, dengan melaksanakan metode yang sesuai dengan bahan pelajaran dan kemampuan anak; 3) menyelenggarakan rapatrapat dengan guru secara insidentil maupun secara priodik yang khusus membicarakan kurikulum, metode mengajar dan sebagainya; 4) mengadakan kunjungan kelas (class visit) yang teratur, mengunjungi guru yang sedang mengajar, untuk meneliti bagaimana cara/ metode mengajarnya, kemudian mengadakan diskusi dengan guru yang bersangkutan; 5) mengadakan kunjungan kelas antara sesama guru-guru (inter class visit); 6) setiap permulaan tahun ajaran baru diwajibkan menyusun suatu silabus mata pelajaran yang akan diajarkan dengan berpedoman kepada rencana pembelajaran yang berlaku di sekolah; 7) pada setiap akhir tahun ajaran masing-masing guru mengadakan penilaian cara dan hasil kerjanya dengan meneliti kembali hal yang pernah diajarkannya, untuk melanjutkannya dan mengadakan perbaikanperbaikan dalam tahun ajaran berikutnya; dan 8) setiap tahun ajaran mengadakan penelitian bersama guru-guru untuk mengetahui situasi dan kondisi pada umumnya dan usaha memperbaikinya (Daryanto, 1998).

Berdasarkan fenomena di atas, setelah melakukan observasi dan wawancara awal di SD Negeri 05 Koto Tangah Kecamatan Tanjung Emas, menurut hemat peneliti strategi Kepala Sekolah dalam meningkatkan kualitas pembelajaran dan etos kerja guru penting untuk dikaji. Penelitian ini dilakukan atas dasar 1) SD Negeri 05 Koto Tangah 
merupakan satu-satunya sekolah yang terpilih menjadi sekolah Rintisan Sekolah Bertaraf Internasional (RSBI) se-Kabupaten Tanah Datar; 2) SD Negeri 05 Koto Tangah ini meski berada di satu Nagari, tetapi sudah dikenal oleh masyarakat sebagai sekolah yang berkualitas; 3) SD Negeri 05 Koto Tangah ini selalu menjadi pilihan utama bagi Wali Murid untuk mendaftarkan anaknya ke sekolah setingkat SD; dan 4) SD Negeri 05 Koto Tangah dapat dikatakan sudah maju, hal ini dapat dilihat dari bangunan fisiknya dan juga fasilitas yang ada. Bangunan sekolah sudah baik, fasilitas yang ada cukup memadai.

\section{METODE PENELITIAN}

Penelitian ini merupakan penelitian yang bercorak kualitatif. Menurut Moleong (1991) data dalam penelitian kualitatif diperoleh melalui literatur dan melalui lisan serta hasil observasi, wawancara dan dokumentasi kemudian dianalisis dan dikompromikan secara kritis. Hanafi (2013) mengatakan bahwa fungsi peneliti dalam penelitian kualitatif adalah sebagai orang yang ingin mencari makna di balik fakta yang kompleks untuk membangun opini baru atau mengkonstruksikannya menjadi pendapat baru berdasarkan fakta-fakta penelitian. Berdasarkan pendapat yang dikemukakan di atas maka pendekatan yang dilakukan dalam penelitian ini dengan melakukan pencarian data melalui leteratur, wawancara, observasi yang intensif. Setelah data dikumpulkan, kemudian dianalisa sehingga mendapatkan data yang valid di samping makna dibalik fakta berdasarkan fakta-fakta penelitian yang telah dilakukan.

Nasution (1992) menjelaskan bahwa dalam penelitian kualitatif, peneliti harus langsung mengumpulkan data dalam situasi yang sesungguhnya. Penelitian kualitatif dimulai dengan menyeleksi suatu situasi sosial tunggal. Tiap situasi sosial mengandung tiga unsur, yaitu adanya tempat, pelaku dan kegiatan. Tempat adalah lokasi di mana manusia melakukan sesuatu. Pelaku ialah semua orang yang terdapat dalam lokasi itu. Kegiatan adalah apa yang dilakukan orang dalam situasi sosial itu. Muliyono (2005) berpendapat bahwa penelitian kualitatif adalah metode penelitian yang digunakan untuk meneliti pada kondisi obyek yang alamiah, di mana peneliti adalah sebagai instrumen kunci, teknik pengumpulan data secara triangulasi (gabungan), analisis data bersifat induktif, dan hasil penelitian kualitatif lebih menekankan makna dari pada generalisasi.

Untuk mewujudkan hal itu peneliti hadir di lokasi penelitian dengan memperlihatkan sikap yang baik terhadap subjek penelitian serta berusaha agar terjalin hubungan yang baik dan keakraban sehingga membuat informan memberikan data yang valid kepada peneliti. Hal ini dilakukan untuk 1) mengungkapkan makna dibalik perilaku manusia; 2) bertujuan menelaah fenomenafenomena sosial budaya dalam suasana yang 
berlangsung secara wajar dan alamiah; 3) akan melihat realitas sosial SD Negeri 05 Koto Tangah ini yang bersifat unik, kompleks namun penuh variasi; dan 4) menetapkan peneliti sebagai instrumen kunci.

Kehadiran peneliti di sekolah tersebut, melakukan pengamatan secara langsung sebagai aktivitas sosial, baik dalam proses pembelajaran di dalam kelas, maupun aktivitas sosial di luar kelas. Ada kalanya juga peneliti melakukan dialog dengan informan mempergunakan bahasa formal yaitu bahasa Indonesia dan bahasa daerah yaitu bahasa Minang.

Sumber data adalah subyek tempat memperoleh data (Arikunto, 2001). Sumber data dalam penelitian ini terdiri dari dua bagian yaitu 1) sumber data primer yang merupakan sumber utama tempat memperoleh data yang sangat dibutuhkan dalam penelitian ini. Sumber data primer adalah Kepala Sekolah yaitu Kepala SD Negeri 05 Koto Tangah, Kecamatan Tanjung Emas, Kabupaten Tanah Datar; dan 2) sumber data sekunder adalah sumber data yang terkait dengan permasalahan yang dibahas sebagai sumber pendukung. Hal ini sesuai dengan pendapat yang dikemukakan oleh Surakhmat (2001) bahwa sumber data sekunder merupakan sumber data yang terkait dengan permasalahan yang dibahas oleh peneliti.

Keberhasilan suatu penelitian terutama penelitian dengan pendekatan kualitatif tergantung pada beberapa faktor antara lain faktor kejelasan tujuan dan permasalahan penelitian, ketepatan pemilihan metodologi, ketelitian dan kelengkapan data serta kemampuan interpretasi atau pemahaman peneliti terhadap data itu sendiri. Yin (2004) mengungkapkan bahwa bukti atau data untuk keperluan penelitian bisa berasal dari enam sumber yaitu dokumen, rekaman arsip, wawancara, pengamatan langsung, observasi partisipan dan perangkat-perangkat fisik. Penggunaan keenam sumber ini memerlukan keterampilan dan prosedur metodologis yang berbeda-beda. Untuk mendapatkan data yang dikumpulkan, maka peneliti akan menggunakan beberapa metode yaitu dokumen, wawancara serta observasi.

Guna memperoleh teori tentang konsep, yang berkaitan dengan pokok permasalahan penelitian, peneliti terlebih dahulu melakukan studi literatur sebagai pembanding terhadap temuan penelitian di lapangan yang kemudian dapat digambarkan dalam bentuk kesimpulan. Setelah data terkumpul dan sebelum peneliti menulis laporan hasil penelitian melalui dokumen, wawancara dan observasi, maka peneliti melakukan analisis terhadap data yang telah dikumpulkan. Menurut Muhadjir (2000) analisis data merupakan upaya mencari dan menata secara sistimatis catatan hasil observasi, wawancara dan lainnya untuk meningkatkan pemahaman yang diteliti dan menyajikannya sebagai temuan bagi orang lain.

Miles dan Huberman (1992) berpendapat bahwa dalam penelitian kualitatif ada tiga 
tahapan analisis yaitu reduksi data, penyajian data dan menarik kesimpulan. Reduksi data adalah pemilihan-pemilihan, pengeditan, pemusatan perhatian pada penyederhanaan, pengabstrakan dan transformasi (pemindahan) data kasar, yang muncul dari catatan tertulis di lapangan. Proses ini berlangsung secara terusmenerus selama penelitian. Kemudian dalam penyajian data, data yang telah disederhanakan disajikan dalam bentuk tulisan, teks naratif yang masih menggambarkan pengertian umum dari apa yang didapati di lapangan. Setelah data disusun, kemudian ditarik kesimpulan dalam bentuk matrik dan narasi. Selanjutnya peneliti menarik kesimpulan yang pada dasarnya merupakan gambaran secara komprehensif dan utuh dari informasi atau data yang diperoleh.

Dalam penelitian ini peneliti menggunakan teori yang dikemukakan oleh Miles dan Hubermen (1992) analisis data dilakukan dengan mereduksi data. Setelah data itu direduksi lalu disajikan dalam bentuk tulisan yang lebih tajam dan jelas. Terakhir peneliti membuat kesimpulan berdasarkan data yang telah diperoleh di lapangan.

\section{HASIL PENELITIAN DAN PEMBAHASAN}

\section{Strategi Kepala Sekolah dalam Meningkatkan Kualitas Pembelajaran}

Dari hasil wawancara yang peneliti lakukan di SDN 05 Koto Tangah, Kecamatan Tanjung Emas bahwa strategi Kepala Sekolah dalam meningkatkan kualitas pembelajaran dilakukan dengan cara antara lain 1) memotivasi guru untuk kreatif dan inovatif; 2) kedisiplinan; 3) memberikan bimbingan dalam menyusun Rencana Pembelajaran; 4) mengadakan supervisi kelas; 5) melengkapi sarana prasarana pendidikan; dan 6) meningkatkan evaluasi pembelajaran.

1) Memotivasi Guru untuk Kreatif dan Inovatif

Peningkatan kualitas pembelajaran di SD Negeri 05 Koto Tangah, bukanlah suatu persoalan yang mudah dilakukan. Hal itu membutuhkan motivasi dan dukungan dari berbagai pihak, seperti halnya motivasi dari Kepala Sekolah, seperti yang diungkapkan oleh Bapak Zulyasri SPd I (guru agama) 12 Februari 2013 bahwa "dorongan motivasi dan juga perhatian dari Bapak Drs. Muslim memberi semangat kepada para guru untuk lebih kreatif dan inovatif dalam proses belajar mengajar di kelas, memberikan reward kepada guru yang berprestasi”.

Bapak Drs. Muslim (13 Februari 2013) sebagai Kepala Sekolah mengatakan bahwa "saya selaku Kepala Sekolah di SDN 05 Koto Tangah ini, berusaha memberikan yang terbaik untuk sekolah ini. Sudah jadi kewajiban bagi saya untuk memotivasi guru dan semua warga sekolah dalam upaya peningkatan kualitas pembelajaran. Motivasi bukan hanya berupa materi saja, bisa juga dalam bentuk bermacam-macam yang lain misalkan dalam bentuk memberikan fasilitas untuk 
pembelajaran. Kalau untuk pembelajaran saya meminta kepada setiap guru agar lebih kreatif dalam kegiatan pembelajaran. Banyak strategi pembelajaran aktif yang dapat diaplikasikan kepada para peserta didik".

Dari observasi yang peneliti lakukan terlihat bahwa motivasi itu tidak saja datang dari Kepala Sekolah, akan tetapi sesama guru atau tenaga pendidik memotivasi dirinya untuk meningkatkan perbaikan dalam inovasi pembelajaran sebagai wujud nyata peningkatan kualitas pembelajaran di SDN 05 Koto Tangah. Hal ini diperkuat oleh seorang guru yaitu Bapak Arlan Ferdianto S.Pd. (13 Februari 2013), mengajarkan Pendidikan Komputer yang mengatakan "selain motivasi yang diberikan oleh Bapak Drs. Muslim selaku Kepala Sekolah, di antara sesama tenaga pendidik juga saling membantu dan saling memotivasi dengan tujuan agar yang kita inginkan dapat diwujudkan".

Berdasarkan dari hasil wawancara dan observasi yang dilakukan dapat diketahui dan disimpulkan bahwa salah satu strategi Kepala Sekolah dalam meningkatkan kualitas pembelajaran adalah dengan memotivasi guru atau para pendidik untuk lebih kreatif dan inovatif dalam proses pembelajaran yang sesuai dengan tema misalkan pada materi shalat jenazah, maka guru Pendidikan Agama Islam (PAI) memakai metode demonstrasi. Tujuannya adalah agar peserta didik dapat memahami dan mengerti serta menghayati bagaimana tata cara shalat jenazah.

\section{2) Kedisiplinan}

Kepala SD Negeri 05 Koto Tangah selalu mengedepankan kedisiplinan baik untuk para guru, maupun peserta didik. Kedisiplinan ini dimulai oleh Kepala Sekolah yaitu Bapak Drs. Muslim. Kepala Sekolah sudah datang ke sekolah sebelum guru datang. Kepala Sekolah menggunakan pola pembinaan guru dengan memberikan contoh berangkat lebih awal dan pulang belakangan. Mulai belajar pada jam pertama 07.30 WIB, maka Kepala Sekolah sudah berada di sekolah lima belas menit sebelum itu. Keadaan ini diperkuat oleh Ibu Yanti Murni S.Pd. (13 Februari 2013) yang mengungkapkan "sikap bapak Kepala Sekolah yaitu Bapak Drs. Muslim sendiri yang sangat disiplin berangkat lebih dahulu atau lebih awal dan pulang lebih akhir atau belakangan dari pada guruguru maupun peserta didik. Hal inilah yang membuat guru-guru segan dan hormat serta turut berdisiplin. Bapak bisa lihat keadaan yang berlangsung di sekolah ini ". Dari penelitian yang peneliti lakukan di SD Negeri 05 Koto Tangah, ucapan Ibu Yanti Murni S.Pd itu memang terlihat di lapangan. Sikap yang dibuat oleh Kepala Sekolah ini menjadikan para guru rajin dan merasa malu jika datang terlambat. 
3) Memberikan Bimbingan dalam Menyusun Rencana Pembelajaran

Rencana Pembelajaran merupakan suatu hal yang sangat penting disusun seoptimal mungkin sebelum dilaksanakannya proses pembelajaran. Terlaksana atau tidaknya proses pembelajaran dengan baik amat tergantung kepada rencana pembelajaran. Oleh karena itu, Kepala Sekolah sebagai supervisor harus mampu membimbing dan mengawasi guru dalam menyusun rencana pembelajaran.

Kepala SD Negeri 05 Koto Tangah (14 Februari 2013) yang diwawancarai menjelaskan bahwa Kepala Sekolah berupaya untuk membimbing guru dalam menyusun rencana pembelajaran. $\mathrm{Hal}$ ini bertujuan agar rencana yang disusun oleh guru betul-betul efektif dan efisien. Namun demikian, Kepala Sekolah tidak bisa mengawasi dan membimbing guru secara individual. Akan tetapi guruguru dibimbing secara kelompok. Dalam hal ini Kepala Sekolah mencari waktu khusus untuk membimbing seluruh guru dan selanjutnya mengadakan diskusi dengan guru-guru. Dengan mengumpulkan guru, maka Kepala Sekolah memberikan pengarahan dan membimbing guru-guru bagaimana menyusun rencana pembelajaran dengan efektif dan efisien.

Pelaksanaan bimbingan yang diberikan Kepala Sekolah terhadap guru-guru dalam menyusun rencana pembelajaran dilaksanakan setiap awal semester, melalui pertemuan khusus. Dalam pertemuan tersebut, guru-guru menerima pengarahan tentang hal yang berhubungan atau berkenaan dengan proses pembelajaran, di antaranya perencanaan pembelajaran, pelaksanaan pembelajaran, dan evaluasi pembelajaran (hasil wawancara dengan Kepala Sekolah SDN 05 Koto Tangah, 14 Februari 2013).

Sehubungan dengan hal yang tersebut di atas, Ibu Yurnailis SPd (15 Februari 2013) salah seorang tenaga pendidik di SDN 05 Koto Tangah melalui wawancara yang dilakukan peneliti, menjelaskan bahwa Kepala Sekolah telah mengadakan bimbingan kepada guru-guru dalam menyusun rencana pembelajaran melalui pertemuan khusus yang diadakan menjelang dilaksanakannya tahun ajaran baru. Pertemuan tersebut dilaksanakan bertujuan agar guru-guru dapat menyusun rencana pembelajaran secara efektif dan efisien. Seorang tenaga pendidik lain yaitu Ibu Sarniati (15 Februari 2013) mengatakan bahwa "kami telah di bimbing oleh Kepala Sekolah dalam menyusun rencana pembelajaran. Sebelum kami melakukan pembuatan rencana pembelajaran, terlebih dahulu kami menerima pengarahan bagaimana membuat rencana pembelajaran sesuai dengan perkembangan dunia pendidikan.

Di antara hal-hal yang diberikan oleh Kepala Sekolah dalam membimbing 
guru-guru dalam menyusun rencana pembelajaran adalah sebagai berikut. a) penguasaan terhadap bahan yang berisikan tentang penguasaan bahan bidang studi dan penguasaan bahan pendalaman bidang studi; b) penyusunan rencana pengelolaan pembelajaran; c) perencanaan pengelolaan kelas yang efektif dan efesien; d) penyusunan rencana penggunaan media pembelajaran; e) penyusunan rencana interaksi proses pembelajaran; dan $\mathrm{f}$ ) penyusunan rencana evaluasi pembelajaran (hasil wawancara dengan Fitriyani 16 Februari 2013).

Hal lain yang dilakukan oleh Kepala Sekolah dalam melakukan bimbingan kepada guru-guru dalam menyusun rencana pembelajaran dapat dikemukakan sebagai berikut.

a) Menempatkan Guru yang Akan Mengajar Sesuai dengan Keahliannya

Di SD Negeri 05 Koto Tangah, ada tenaga honorer untuk pendidik sebanyak 5 orang. Hal ini terjadi disebabkan guru yang telah menjadi PNS belum mencukupi sesuai dengan rombel dan mata pelajaran yang harus diampu. Untuk mengatasi keadaan ini Kepala Sekolah menerima tenaga honorer dengan kriteria persyaratan kedisiplinan ilmu yang dibutuhkan serta sesuai dengan bidang mata pelajaran yang akan diampunya. Kebijakan ini dilakukan oleh Kepala Sekolah dengan tujuan agar Kepala Sekolah tidak mengalami kesulitan yang berarti dalam membimbing guru menyusun rencana pembelajaran (observasi terhadap kebijakan kepala SDN 05 Koto Tangah, Sabtu 16 Februari 2013).

Dari data yang dikemukakan di atas, dapat diketahui bahwa upaya yang dilakukan Kepala Sekolah untuk membimbing guru dalam menyusun rencana pembelajaran adalah dengan menetapkan dan menempatkan guru sesuai dengan keahliannya sehingga tidak banyak menghadapi kesulitan dalam membimbing guru.

b) Memberikan Kesempatan Kepada Guru untuk Mengikuti Pelatihan

Dalam membimbing guru-guru menyusun rencana pembelajaran, maka Kepala Sekolah juga memberikan kesempatan kepada guru untuk mengikuti berbagai pelatihan yang berkenaan dengan pendidikan. Hal ini diungkapkan Kepala Sekolah (18 Februari 2013) "meskipun guru-guru diberikan tugas mengajar atau rombel sesuai dengan keahliannya, namun Kepala Sekolah juga memberikan kesempatan kepada guru untuk mengikuti berbagai pelatihan yang berkenaan dengan pendidikan baik yang diadakan di tingkat daerah maupun yang dilakukan di tingkat propinsi”. 
Sehubungan dengan itu seorang guru yang diwawancarai yaitu Ibu Ermiwati S.Pd. (18 Februari 2013) mengatakan bahwa Kepala Sekolah mengutus guru-guru untuk mengikuti berbagai perlatihan pendidikan baik yang diadakan di tingkat daerah maupun di tingkat propinsi, dengan tujuan agar guru mengetahui perkembangan dunia pendidikan. Pemberian kesempatan tersebut merupakan hal yang sangat mendukung bagi kami guru-guru. Tidak hanya dalam menyusun rencana pembelajaran, akan tetapi mempunyai arti yang sangat penting bagi dunia pendidikan.

Apabila guru telah kembali dari mengikuti berbagai pelatihan yang berkenaan dengan pendidikan, maka Kepala Sekolah tidak hanya meminta pertanggung jawaban secara individual antara pimpinan dengan bawahan. Dalam hal ini Kepala Sekolah meminta guru yang diutus tersebut untuk mempresentasikan hasil pelatihan di hadapan guru-guru lain secara bersama pada waktu yang ditentukan, sehingga berbagai bentuk perkembangan dunia pendidikan diketahui secara merata oleh guru-guru lainnya (hasil wawancara dengan Yulia Dharma SPd, 18 Februari 2013).

Dari data yang dikemukakan di atas, dapat diketahui bahwa dalam membimbing guru menyusun rencana pembelajaran, Kepala Sekolah memberikan kesempatan dan mengutus guru secara bergantian untuk mengikuti berbagai pelatihan yang berkenaan dengan pendidikan.

c) Mengadakan Pertemuan Khusus dengan Guru-Guru

Pertemuan khusus antara Kepala Sekolah dengan guruguru merupakan pertemuan yang bertujuan membicarakan sesuatu kendala atau hambatan yang dihadapi oleh guru dalam melaksanakan proses pembelajaran. Dalam pertemuan tersebut dibicarakan juga tentang perkembangan anak oleh masing-masing guru kelas dan kemudian dibicarakan solusi atau jalan keluar secara bersama bagi guru kelas yang menghadapi kesulitan. Salah seorang guru dalam wawancara menjelaskan bahwa "Kepala Sekolah mengadakan pertemuan dengan guru-guru minimal satu kali dalam dua bulan untuk membicarakan berbagai perkembangan pendidikan termasuk membicarakan hambatan yang dihadapi oleh peserta didik. Tetapi kalau ada persoalan mendesak yang harus diatasi, maka pertemuan itu segera dilaksanakan" (hasil wawancara dengan Ulfianti S.Pd, 19 Februari 2013). 
Kepala Sekolah (19 Februari 2013) yang diwawancarai juga menegaskan bahwa untuk mengetahui bagaimana pelaksanaan proses pembelajaran oleh guru termasuk berbagai kendala yang dihadapi guru dalam proses pembelajaran, maka setiap satu kali dalam dua bulan diadakan pertemuan dengan seluruh guru. Melalui pertemuan ini guru-guru dapat menyampaikan dan mengungkapkan berbagai keluhan dalam proses pembelajaran.

Sehubungan dengan hal itu seorang guru yang di wawancarai juga menjelaskan bahwa meskipun di awal semester Kepala Sekolah telah memberikan bimbingan dan terhadap guru dalam menyusun rencana pembelajaran, namun rencana itu bisa saja berubah di tengah semester sesuai dengan kondisi yang di hadapi oleh guru dalam melaksanakan proses pembelajaran (hasil wawancara dengan Harlenawati S.Pd, 20 Februari 2013).

Dari data yang dikemukakan di atas dapat diketahui bahwa Kepala Sekolah telah mengadakan pertemuan khusus dengan guruguru dalam rangka memberikan bimbingan untuk menyusun rencana pemebelajaran di SD Negeri 05 Koto Tangah Kecamatan Tanjung Emas, Kabupaten Tanah Datar.

\section{4) Mengadakan Supervisi Kelas}

Sepervisi kelas dilakukan oleh Kepala Sekolah bertujuan untuk meningkatkan kemampuan guru dalam proses belajar mengajar. Melalui upaya menganalisis berbagai tingkah laku pada saat melaksanakan proses belajar mengajar. Karena ada hal-hal yang semestinya dilakukan oleh guru ketika melaksanakan proses pembelajaran di antaranya a) membuka pelajaran dengan baik, sehingga minat siswa mengikuti proses belajar mengajar tetap terpelihara; b) melakukan pengelolaan kelas, agar situasi kelas berjalan sebaik mungkin; c) memberikan penjelasan materi sebaik mungkin, sehingga peserta didik dapat memahami materi yang disampaikan; d) bertanya kepada peserta didik tentang materi yang disampaikan, sehingga hal ini menjadi acuan bagi guru untuk melanjutkan ke materi berikutnya; e) menggunakan metode sesuai dengan materi pelajaran; dan f) menggunakan media pembelajaran apabila diperlukan (hasil wawancara dengan Drs. Muslim, 20 Februari 2013). Berdasarkan observasi yang telah peneliti lakukan, mengenai supervisi kelas ini, Kepala Sekolah telah melakukannya. Hasil dari supervisi kelas yang ditemukan oleh Kepala Sekolah, kemudian mendiskusikannya bersama guru mata pelajaran yang bersangkutan dan mencari jalan keluar atas persoalan yang ditemukan. 
5) Melengkapi Sarana Prasarana Pendidikan

Untuk meningkatkan efektifitas pembelajaran SD Negeri 05 Koto Tangah Kecamatan, Kepala Sekolah bersama stakeholders melengkapi sarana dan prasarana yang merupakan salah satu faktor yang cukup menentukan bagi pencapaian tujuan pendidikan seperti infocus, komputer dan lain-lain (hasil wawancara dengan Drs. Muslim, 20 Februari 2013). Apabila pendidikan diselenggarakan dengan sarana dan prasarana yang memadai, maka tujuan yang akan dicapai dapat diperoleh dengan efektif dan efisien dan demikian pula sebaliknya.

\section{6) Meningkatkan Evaluasi Pembelajaran}

Berdasarkan hasil penelitian di lapangan, peneliti menemukan bahwa Kepala SD Negeri 05 Koto Tangah, dalam meninggkatkan evaluasi pembelajaran melakukan evaluasi tentang program pembelajaran, proses pembelajaran dan hasil pembelajaran. Evaluasi tentang program pembelajaran misalnya peneliti menemukan bahwa Kepala Sekolah telah melakukan pemantauan terhadap guruguru apakah guru itu membuat program pembelajaran atau tidak yang diminta. Guru yang tidak atau belum membuat program pembelajaran baik semester maupun tahunan, selalu disarankan agar secepat mungkin membuatnya. Dalam hal ini Kepala Sekolah sangat mengontrol secara berkesinambungan agar guru mempunyai tanggung jawab terhadap kegiatan mengajarnya di sekolah.

Evaluasi mengenai proses pembelajaran, peneliti juga melihat bahwa Kepala Sekolah melakukan supervisi pelaksanaan pembelajaran di kelas. Hal ini dilakukan oleh Kepala Sekolah untuk melihat dan mengetahui apakah proses pembelajaran di kelas berlangsung dinamis, bersemangat, aktif dan menyenangkan peserta didik.

Mengenai evaluasi tentang hasil pembelajaran, Kepala Sekolah melihatnya dari persentase siswa yang betul-betul sudah menguasai secara keseluruhan dan yang belum sama sekali. Data ini dianalisis dari persentase peserta didik yang tuntas atau tidak mengikuti ulangan harian. Dari sini akan terlihat apakah tujuan pembelajaran secara umum sudah mencapai target yang diharapkan atau belum dan juga tingkat pencapaian peserta didik terhadap tujuantujuan umum pembelajaran itu sudah maksimal, baru setengah-setengah atau belum tercapai sama sekali.

\section{Etos Kerja Guru dalam Meningkatkan Kualitas Pembelajaran}

Setelah Kepala SD Negeri 05 Koto Tangah melakukan dan melaksanakan strategi dalam meningkatkan kualitas pembelajaran, dengan jalan pendekatan yang bersikap demokratis dan kekeluaragaan menjadikan guru termotivasi untuk lebih kreatif dan kedisiplinan. Tanpa ada perintah dari Kepala Sekolah guru di SDN 05 menyadari bahwa 
mereka harus melaksanakan kedisiplinan baik dalam kedatangan ke sekolah maupun dalam proses belajar mengajar. Dalam penelitian yang peneliti lakukan terlihat bahwa guruguru telah hadir di sekolah lima belas menit sebelum jam pertama berlangsung. Di SD Negeri 05 jam pertama mulai jam 07.30 WIB. Guru agama menjelaskan bahwa mengenai kedisiplinan sebenarnya tidak mesti di tegaskan atau dipaksakan oleh Kepala Sekolah untuk berdisiplin. Akan tetapi seharusnya guru itulah yang harus mendisiplinkan dirinya sendiri. Karena setiap guru harus menyadari bahwa apa yang dilakukan oleh guru akan digugu dan ditiru atau dicontoh oleh peserta didik. Karena itu setiap guru harus selalu mendisiplinkan diri. Pengawasan yang dilakukan oleh Kepala Sekolah seharusnya hanya mengingatkan untuk kebaikan bersama (hasil wawancara dengan Zulyasri S.Pd.I, Jum'at 01 Maret 2013).

Setelah peneliti menerima keterangan dari Kepala Sekolah, peneliti dapat memahami bahwa selama ini strategi yang dilakukan Kepala Sekolah mengubah pola pikir dan perilaku guru yang ada di sekolah. Keadaan ini terlihat dari kegiatan guru dalam penguasaan bahan ajar secara benar dan tepat waktu sehingga peserta didik semakin termotivasi untuk belajar. Para guru mengembangkan kepribadiannya sebagai pengajar dan pendidik yang bertanggung jawab dan mengerti keadaan peserta didik serta dapat berkomunikasi secara baik dengan para peserta didik. Di samping para guru atau pendidik di SD Negeri 05
Koto Tangah kecamatan Tanjung Emas telah membiasakan melaksanaan kedisiplinan dalam meningkatkan kualitas pembelajaran, maka tenaga kependidikan dan peserta didik dengan kesadaran juga berusaha meniru atau mencontoh yang dilakukan oleh para pendidik.

Temuan dalam penelitian ini seirama dengan temuan Taufik (2008) bahwa ada pengaruh yang positif antara kepemimpinan Kepala Sekolah dengan kinerja guru PAI dan ada juga pengaruh signifikan antara kepemimpinan Kepala Sekolah dan motivasi kerja guru PAI terhadap kinerjanya. Kedua, temuan penelitian ini didukung dengan temuan Hamid (2004) bahwa sebagian besar Kepala Sekolah memiliki gaya kepemimpinan partisipatif. Gaya kepemimpinan Kepala Sekolah secara keseluruhan berada dalam kategori efektif. Gaya kepemimpinan Kepala Sekolah berkorelasi positif dengan kinerja guru. Hal ini berarti semakin efektif gaya kepemimpinan yang diterapkan oleh Kepala Sekolah, maka kinerja guru semakin meningkat.

\section{KESIMPULAN}

Strategi Kepala Sekolah dalam meningkatkan kualitas pembelajaran dilakukan dengan cara antara lain 1) memotivasi guru untuk kreatif dan inovatif; 2) kedisiplinan; 3) memberikan bimbingan dalam menyusun Rencana Pembelajaran; 4) mengadakan supervisi kelas; 5) melengkapi sarana prasarana pendidikan; dan 6) meningkatkan evaluasi pembelajaran. Strategi yang dilakukan Kepala Sekolah ini mengubah pola pikir dan perilaku 
guru yang ada di sekolah. Keadaan ini terlihat dari kegiatan guru dalam penguasaan bahan ajar secara benar dan tepat waktu sehingga peserta didik semakin termotivasi untuk belajar. Para guru mengembangkan kepribadiannya sebagai pengajar dan pendidik yang bertanggung jawab dan mengerti keadaan peserta didik serta dapat berkomunikasi secara baik dengan para peserta didik.

\section{KEPUSTAKAAN ACUAN}

Amantembun, N.A. (1982). Penyusunan Program Kerja Sekolah. Bandung: Transito.

Arikunto, Suharsimi. (2001) Prosedur Penelitian, Suatu Pendekatan Praktek. Jakarta: Rineka Cipta.

Azzabidi, Abul Abbas. (1996). Himpunan Hadis Sahih Pilihan. Terjemahan dari Attajridush Sharih li Alhadiis Jamiush Shahih oleh Bahrun Abubakar \& Sofyan Suparman. Bandung: Trigenda Karya

Daryanto, H.M. (1998). Administrasi Pendidikan. Jakarta: Rineka Cipta.

Departemen Agama RI. (2006). UndangUndang dan Peraturan Pemerintah RI tentang Pendidikan Nasional. Jakarta: Derektorat Jenderal Pendidiklan Islam Departemen Agama RI.

Hamid, Abdul. (2004). Gaya Kepemimpinan Kepala Sekolah dan Motivasi Kerja Hubungannya dengan Kinerja Guru SMP Negeri di Kabupetan Kudus. Semarang: UNNES.
Hanafi, Abdul Halim. (2013). Metode Penelitian Kependidikan. Batusangkar: STAIN Batusangkar Press.

Miles, Mathew dan Huberman. (1992). Qualitative Data Analysis. Terjemahan Tjetjep Rohadi. Jakarta: UI Press.

Moleong, Lexy J. (1991). Metodologi Penelitian Kualitatif. Bandung: Remaja Rosda Karya.

Muhadjir, Noeng. (2000). Metode Penelitian Kualitatif. Yagyakarta: Rike Sarasin.

Muliyono. (2005). Mengenal Penelitian Kualitatif. Bandung: Alfabeta.

Mulyasa, H.E. (2012). Manajemen \& Kepemimpinan Kepala Sekolah. Jakarta: Bumi Aksara.

Nasution, S. (1992). Metode Penelitian Naturalistik Kualitatif. Bandung: Tarsito.

Surachmat, Winarno. (2001). Penelitian Pendidikan. Jakarta: Rineka Cipta.

Taufik, Alinur. (2008). Pengaruh Kepemimpinan Kepala Sekolah dan Motivasi Kerja terhadap Kinerja atau Penelitian pada Guru PAI SMA se-Kabupaten Demak. Semarang: IAIN Wali Songo.

Undang-Undang Nomor 20 Tahun 2003 tentang Sistem Pendidikan Nasional.

Yin, Robert K. (2004). Studi Kasus Desain dan Metode. Terjemahan M.Jauzi Muzakkir. Jakarta: PT. Raja Grafindo Persada. 